\section{Polymorphic DNA microsatellites identified in the yellow dung fly (Scathophaga stercoraria)}

\author{
T. W. J. GARNER, ${ }^{*}$ H. BRINKMANN, + \\ G. GERLACH, + A. MEYER, †. I. WARD, $\neq$ \\ M. SPÖRRI* and D. J. HOSKEN
}

\begin{abstract}
*Zoologisches Institut and $\ddagger$ Zoological Museum, Universität Zürich-Irchel, Winterthurerstrasse 190, Zürich, Switzerland, +Faculty of Biology, Box 5560, University of Konstanz, D-78434 Konstanz, Germany
\end{abstract}

Keywords: microsatellites, Scathophaga stercoraria, sperm competition, yellow dung fly

Received 15 August 2000; revision accepted 2 September 2000

Correspondence: T. W. J. Garner. Fax: + 4163568 21; E-mail: twjg@zool.unizh.ch

Sperm competition in yellow dung flies (Scathophaga stercoraria) has been extensively investigated since Parker's (1970a) seminal work (e.g. Parker \& Simmons 1991; Ward 1993; Hosken \& Ward 2000; reviewed in Hosken 1999). These flies serve as a model system for understanding the mechanisms and outcomes of sperm competition in internal fertilizers. Invariably however, these investigations have been laboratory based, and typically involved competition between only two males. How the results of such studies relates to freeliving flies is unknown, but it is unlikely that the experimental conditions employed exist in nature, and therefore outcomes may not reflect true female sperm utilization patterns (Eady \& Tubman 1996). This is exemplified by a study of sperm competition in pseudoscorpions, which showed that secondmale mating advantage breaks down when females mate with more than two males (Zeh \& Zeh 1994). In addition, Ward (2000) has shown that females are able to subtly alter paternity patterns under conditions that are likely to be common in the field. With this in mind, our aim was to develop appropriate genetic markers to allow paternity to be accurately assigned in clutches laid by free-living female yellow dung flies.

A subgenomic library enriched for CA repeat microsatellites was constructed following standard protocols outlined in Tenzer et al. (1999), with slight modifications. Genomic DNA isolated from a single $S$. stercoraria male using standard phenolchloroform extraction and ethanol precipitation (Sambrook et al. 1989) was digested using Tsp509I (New England Biolabs). A 500-1000 bp size fraction was isolated from a LM-MP agarose (Boehringer Mannheim) gel by first excising the appropriate size range from the gel. The gel fragment was melted in a $65^{\circ} \mathrm{C}$ water bath and volume was increased to $500 \mu \mathrm{L}$ using double distilled water. An equal volume of equilibrated phenol ( $\mathrm{pH}$ 8.0) was added, the solution vortexed briefly and then put at $-80^{\circ} \mathrm{C}$ for $30 \mathrm{~min}$. The sample was then thawed and extraction was completed following standard phenol-chloroform extraction methods (Sambrook et al. 1989). This isolate was used for ligation with TSPADSHORT/ TSPADLONG linkers (Tenzer et al. 1999) and then amplified via the polymerase chain reaction (PCR), using TSPADSHORT as a primer. PCR was performed using the following conditions: Total reaction volume was $25 \mu \mathrm{L}$ included $100 \mathrm{ng}$ DNA,
1 U Taq DNA polymerase (Quantum-Appligene), $10 \mathrm{~mm}$ Tris- $\mathrm{HCl}$, pH 9.0, $50 \mathrm{~mm} \mathrm{KCl}, 1.5 \mathrm{~mm} \mathrm{MgCl}_{2}, 0.01 \%$ TritonX100, $0.2 \mathrm{mg}$ BSA (Quantum-Appligene), $100 \mu \mathrm{M}$ of each dNTP (Promega), and $1 \mu \mathrm{M}$ of TSPADSHORT. PCR was performed on a Techne Genius thermocycler (Techne Ltd) using the following thermotreatment: $2 \mathrm{~min}$ at $72{ }^{\circ} \mathrm{C}$, followed by 25 cycles of $1 \mathrm{~min}$ at $94{ }^{\circ} \mathrm{C}, 1 \mathrm{~min}$ at $55^{\circ} \mathrm{C}$, and $1 \mathrm{~min}$ at $72{ }^{\circ} \mathrm{C}$. A total of 32 PCRs were carried out, pooled, cleaned and concentrated to minimize the likelihood of redundant products being detected during screening for positive clones. PCR products were hybridized to biotinylated $(\mathrm{CA})_{20}$ probes bonded to streptavidin-coated magnetic beads (Dynabeads M-280 Streptavadin, DYNAL, France) and amplified again. These final PCR products were cloned following the Original TA Cloning ${ }^{\circledR}$ Kit (Invitrogen) protocol. White colonies were dot-blotted onto nylon membranes (Hybond ${ }^{\mathrm{TM}}-\mathrm{N}^{+}$, Amersham Pharmacia) and screened for CA repeats using the ECL 3 '-oligolabelling and detection system (Amersham Pharmacia) and a 40mer CA oligonucleotide. All positive clones were sequenced following the ABI Prism ${ }^{\circledR}$ BigDye ${ }^{\mathrm{TM}}$ Terminator Cycle Sequencing Ready Reaction Kit protocol, version 2.0 (PE Biosystems) using M13 forward and reverse primers, and using the ABI 377 automated sequencing system (PE Biosystems). Primers were designed using Primer3 software (Rozen \& Skaletsky 1998) and all oligonucleotides were synthesized by Microsynth $\mathrm{GmbH}$ (Switzerland). Initial tests for amplification and polymorphism were carried out at $55^{\circ} \mathrm{C}$ and electrophoresed on $8 \%$, nondenaturing, $14.5 \mathrm{~cm}$ $\times 17 \mathrm{~cm}$ acrylamide gels at $80 \mathrm{~V}$ overnight. Those primers that amplified polymorphic products using five test templates were used for all following analyses.

Only field-caught male S. stercoraria were used for PCR analysis, as almost every field-caught female is already mated (Parker 1970b), and extraction from fertilized females could therefore result in contamination by sperm DNA. Each sample male was extracted using the QIAamp® DNA mini kit (Qiagen). Twenty males were used to characterize suitable primers, and PCR was carried out using approximately $100 \mathrm{ng}$ of template DNA and the following cycle treatment; initial step of $3 \mathrm{~min}$ at $94^{\circ} \mathrm{C}$, followed by 27 cycles of $30 \mathrm{~s}$ at $94{ }^{\circ} \mathrm{C}, 30 \mathrm{~s}$ at $58-61{ }^{\circ} \mathrm{C}$ (see Table 1 ), and $30 \mathrm{~s}$ at $72{ }^{\circ} \mathrm{C}$, with a final extension step of $2 \mathrm{~min}$ at $72{ }^{\circ} \mathrm{C}$. Total reaction volume was $25 \mu \mathrm{L}$ and contained $10 \mathrm{~mm}$ Tris- $\mathrm{HCl}, \mathrm{pH} 9.0,50 \mathrm{~mm}$ $\mathrm{KCl}, 1.5 \mathrm{~mm} \mathrm{MgCl}_{2}, 0.01 \%$ Triton $\times 100,0.2 \mathrm{mg}$ BSA (QuantumAppligene), $100 \mu \mathrm{M}$ of each dNTP (Promega), $0.5 \mu \mathrm{M}$ of both forward and reverse primer, and 0.5 U Taq DNA polymerase (Quantum-Appligene). All products were electrophoresed on Spreadex ${ }^{\mathrm{TM}}$ EL-300 S-100 gels (Elchrom Scientific AG, Switzerland), using the SEA $2000^{\mathrm{TM}}$ advanced submerged gel electrophoresis apparatus (Elchrom Scientific AG, Switzerland). Gels were run at $100 \mathrm{~V}$ for $80-90 \mathrm{~min}$, depending on allele sizes, then scored against the M3 Marker ladder (Elchrom Scientific AG, Switzerland). Expected and observed counts for homozygotes/heterozygotes were determined using GENEPOP version 3x (Raymond \& Rousset 1995) and homozygote excess was tested for using Chi-square analysis (null hypothesis rejected at $P<0.05$ ).

A minimum of five alleles were detected at each of the loci listed in Table 1. Tests for homozygote excess were only 
Table 1 Primer sequence and related information for eight microsatellite loci developed for Scathophaga stercoraria. Both repeat motif and size of amplification product are based on that detected in the original sequenced clone (GenBank Accession nos: AF292121-8). $n$, number of individuals tested; $T_{\mathrm{a}}$, annealing temperature; $H_{\mathrm{O}}$, observed number of homozygotes; $H_{\mathrm{E}}$, unbiased average heterozygosity estimate (Nei 1978)

\begin{tabular}{|c|c|c|c|c|c|c|c|c|}
\hline Locus & Primer Sequences $\left(5^{\prime}-3^{\prime}\right)$ & Repeat motif & $\mathrm{T}_{\mathrm{a}}\left({ }^{\circ} \mathrm{C}\right)$ & $n$ & No. alleles & Size (bp) & $H_{\mathrm{O}}$ & $H_{\mathrm{E}}$ \\
\hline $\mathrm{SsCA} 3$ & $\begin{array}{l}\text { ССТСААСССССТСАСТСАС } \\
\text { САТСАТСАТTTАAGTCAАСАTTAGAAA }\end{array}$ & $\begin{array}{l}(\mathrm{AC})_{1}(\mathrm{~A})_{2}(\mathrm{AC})_{11} \\
(\mathrm{~A})_{3}(\mathrm{C})_{2}(\mathrm{~A})_{3}\end{array}$ & 60 & 20 & 11 & 120 & 0.35 & 0.795 \\
\hline SsCA16 & $\begin{array}{l}\text { GACTTTGGTCCGTTGTAGTCC } \\
\text { TTGGCGTCACCATACTCAAC }\end{array}$ & $\begin{array}{l}(\mathrm{C})_{3} \mathrm{AT}(\mathrm{AC})_{11} \mathrm{AT} \\
(\mathrm{AC})_{2}(\mathrm{C})_{3}\end{array}$ & 60 & 20 & 7 & 101 & 0.10 & 0.806 \\
\hline SsCA17 & $\begin{array}{l}\text { AATAAAAACTCAACCAACCATACAC } \\
\text { CCTTACTCGATAAGTTGGTATTTGTG }\end{array}$ & $\begin{array}{l}(\mathrm{TA})_{2} \mathrm{GA}(\mathrm{CA})_{4} \mathrm{CG} \\
(\mathrm{CA})_{5}\end{array}$ & 60 & 18 & 6 & 108 & 0.40 & 0.695 \\
\hline $\mathrm{SsCA} 20$ & $\begin{array}{l}\text { TGTTTGCTGGTGCTACCG } \\
\text { TGATCGTTGTTGTTTCATACG }\end{array}$ & $(\mathrm{CA})_{10}$ & 60 & 18 & 5 & 120 & 0.55 & 0.600 \\
\hline $\mathrm{SsCA} 24$ & $\begin{array}{l}\text { CACACACTCGCAGCTACACC } \\
\text { AAACTTTAACTTCGATTTTTGCTG }\end{array}$ & $(\mathrm{C})_{4} \mathrm{AT}(\mathrm{AC})_{9}$ & 60 & 20 & 8 & 120 & 0.30 & 0.821 \\
\hline SsCA26 & $\begin{array}{l}\text { TGCCACTTTTGGTGCTTTC } \\
\text { CAGCAAAAACCGGCAAAC }\end{array}$ & $\begin{array}{l}(\mathrm{CA})_{11}(\mathrm{~T})_{2}(\mathrm{CA})_{2} \mathrm{CG}(\mathrm{CA})_{4} \mathrm{CG} \\
(\mathrm{CA})_{4}(\mathrm{~T})_{2}(\mathrm{CA})_{2}(\mathrm{~T})_{2}(\mathrm{GTT})_{2}\end{array}$ & 61 & 20 & 8 & 110 & 0.25 & 0.845 \\
\hline SsCA28 & $\begin{array}{l}\text { GTTTGAAACCCTTAAGATAAAAACTC } \\
\text { CCATCTTTCACGGGATTTTG }\end{array}$ & $\begin{array}{l}(\mathrm{CT})_{2}(\mathrm{CA})_{5} \mathrm{AACG} \\
(\mathrm{CA})_{10}\end{array}$ & 58 & 20 & 13 & 127 & 0.35 & 0.890 \\
\hline Ss63T7 & $\begin{array}{l}\text { AAAGAATTTTACGAATTGTGTCTGG } \\
\text { CAACAAATGCAACAAATGACC }\end{array}$ & $(\mathrm{CA})_{6}(\mathrm{~A})_{2}(\mathrm{CA})_{8}$ & 58 & 18 & 8 & 129 & 0.20 & 0.869 \\
\hline
\end{tabular}

significant at one locus, SsCa28, which may suggest one or more null alleles operating at this locus.

\section{Acknowledgements}

We would like to thank Tony Wilson and Jens Seckinger for their help. This work was funded in part by an Alexander Von Humboldt Stiftung awarded to DJH, and grants from the Swiss National Foundation (SNF 31-56902.99 to DJH, SNF 31-46861.96 to PIW, SNF 31-40688.94 to H-U Reyer). AM would also like to thank the Deutsche Forschungsgemeinschaft and AM and GG acknowledge the contribution of the Verband der Chemischen Industrie.

\section{References}

Eady P, Tubman S (1996) Last-male sperm precedence does not break down when females mate with three males. Ecological Entomology, 21, 303-304.

Hosken DJ (1999) Sperm displacement in yellow dung flies: a role for females. Trends in Ecology and Evolution, 14, 251252.

Hosken DJ, Ward PI (2000) Copula in yellow dung flies (Scathophaga stercoraria): investigating sperm competition models by histological observation. Journal of Insect Physiology, 46, 1355-1363.

Nei M (1978) Estimation of average heterozygosity and genetic distance from a small number of individuals. Genetics, 89, 583-590.

Parker GA (1970a) Sperm competition and its evolutionary consequences in insects. Biological Reviews, 45, 525-567.

Parker GA (1970b) Sperm competition and its evolutionary effect on copula duration in the fly, Scatophaga stercoraria. Journal of Insect Physiology, 16, 1301-1328.

Parker GA, Simmons LW (1991) A model of constant random sperm displacement during mating: evidence from Scatophaga. Proceedings of the Royal Society of London, Series B, 246, 157-166.
Raymond M, Rousset F (1995) GENEPOP (Version 1.2): Population genetics software for exact tests and ecumenism. Journal of Heredity, 86, 248-249.

Rozen S, Skaletsky HJ (1998) Primer3. Code available at http://www-genome.wi.mit.edu/genome_software/other/ primer3.html.

Sambrook J, Fritsch EF, Maniatis T (1989) Molecular Cloning: a Laboratory Manual, 2nd edn. Cold Spring Harbor Laboratory Press, New York.

Tenzer I, degli Ivanissevich S, Morgante M, Gessler C (1999) Identification of microsatellite markers and their application to population genetics of Venturia inaequalis. Phytopathology, 89, 748-753.

Ward PI (1993) Females influence sperm storage and use in the yellow dung fly Scathophaga stercoraria (L.). Behavioral Ecology and Sociobiology, 32, 313-319.

Ward PI (2000) Cryptic female choice in the yellow dung fly Scathophaga stercoraria (L.). Evolution, in press.

Zeh JA, Zeh DW (1994) Last-male sperm precedence breaks down when females mate with three males. Proceedings of the Royal Society of London, Series B, 257, 287-292. 